\title{
History of the paleo-earthquakes along the Sagami Trough, central Japan: Review of coastal paleo- seismological studies in the Kanto region
}

Development of recent research of crustal movement of Japan, Geological Survey of Japan, National Institute of Advanced Science and Technology (AIST), Tsukuba 305-8567, Japan. E-mail: m.shishikura@aist.go.jp

Two subduction zone interplate earthquakes have been recorded along the Sagami Trough, the first in $A D$ 1703 (Genroku Earthquake) and the second in AD 1923 (Taisho Earthquake). While the source areas of these two events overlapped within and around the Sagami Bay, the 1703 Genroku Earthquake had a larger rupture area, which propagated to off the Boso Peninsula. Currently, our understanding of prehistorical earthquakes has been facilitated by Holocene marine terraces and tsunami deposits, through which we have come to the understanding that past Kanto earthquakes can be divided into two types - the Taisho-type and the Genrokutype. Taisho-type earthquakes are thought to be more common, occurring approximately every 400 years on average, but after several occurrences (at 2,000-2,700 year intervals) a Genroku-type earthquake would take place and propagate to off the Boso Peninsula. These less frequent coseismic Genroku-type ruptures are not consistent with global navigation satellite system (GNSS) geodetic data, which show strong plate interface coupling in this area due to a high slip-deficit rate. To resolve this discrepancy, it is necessary to consider hypotheses such as changes to the long-term slip-deficit rate, the occurrence of aseismic fault slips, or even the existence of another earthquake type. Furthermore, recent marine terrace survey reports in the Boso Peninsula have shown that the emergent ages between the eastern coast and western coast do not necessarily correlate, which lends credence to the possibility that another earthquake type occasionally occurs in the region off the Boso Peninsula.

\section{Introduction}

Located off the Kanto region of central Japan (which includes the Tokyo metropolitan area), the Sagami Trough is a convergent plate boundary extending from Sagami Bay to the area off the Boso Peninsula where the Philippine Sea Plate subducts beneath the
North American Plate (Fig. 1). While historical records show that two great earthquakes, the 1703 Genroku Kanto Earthquake (M 8.2) and the 1923 Taisho Kanto Earthquake (M 7.9) (hereafter, the 1703 Genroku Earthquake and the 1923 Taisho Earthquake, respectively), occurred along this trough (Usami et al., 2013), records of earthquakes occurring before the 1703 Genroku Earthquake are ambiguous.

However, instead of concentrating on the few remaining historical records of past eras, tectonic geomorphological studies have aimed at recovering information on past earthquakes from marine terraces. Such studies have been conducted since the coseismic uplift associated with the 1923 Taisho Earthquake was discovered along the coasts facing the Sagami Trough (Imamura, 1925; Watanabe, 1929). Although the progress of paleoseismological records of the past 40 years in this area has helped elucidate the history and cycle of interplate earthquakes along the Sagami Trough (e.g. Shishikura, 2003), the observed results do not fully agree with more recently obtained geodetical observation data. The resulting contradictions are very important, not only in terms of scientific understanding, but also because of their relevance when formulating disaster prevention plans for metropolitan areas. In fact, Japanese government offices tasked with disaster prevention measures have recently announced seismic hazard breakdowns for Japan's metropolitan areas (Cabinet Office, 2013; Earthquake Research Committee, 2014), but those efforts did not consider this problem in detail.

Therefore, in this paper, I will provide an overview of current research into paleoearthquakes and associated tsunami events in this region, discuss the distribution of the region's seismically active faults, and then examine their possible slip recurrence, terrace uplift magnitudes, and tsunami deposit records.

\section{Historical earthquakes and tsunamis along the Sagami Trough}

\section{Taisho Kanto Earthquake}

The 1923 Taisho Kanto Earthquake, which killed more than 105,000 people, was one of the worst natural disasters in recorded Japanese history (Moroi and Takemura, 2004). Significant crustal movements and tsunamis accompanied this earthquake.

According to tide gauge data and the re-leveling of benchmarks and triangular points undertaken by the Land Survey Department (1926), the Boso Peninsula, Miura Peninsula, and Oiso coastal area 


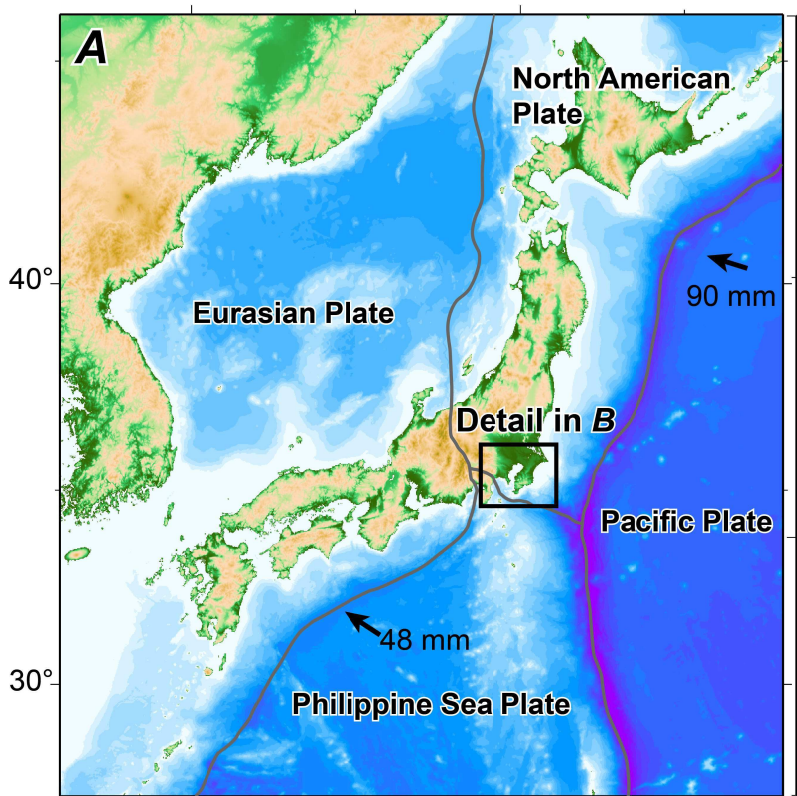

$130^{\circ}$

$140^{\circ}$

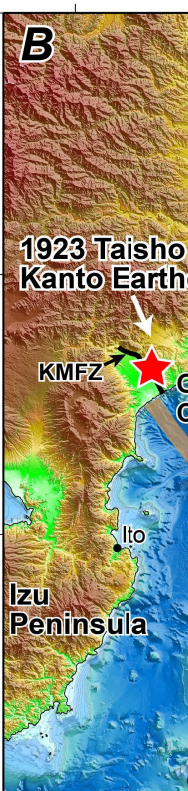

$139^{\circ}$
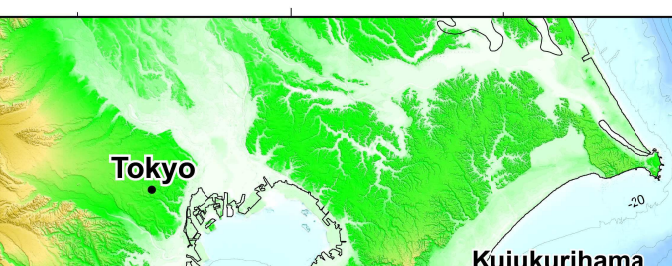

$36^{\circ}$

Figure 1. Tectonic setting of Japan Islands (A) and study areas in Kanto region (B). KMFZ: Kozu-Matsuda Fault Zone. Red stars in B are epicenter of main shock during historical earthquakes. Plate motion is after Bird (2003) and Uchida et al. (2009).

were uplifted by as much as $2 \mathrm{~m}$ and moved horizontally 2-3 $\mathrm{m}$ during the 1923 earthquake (Fig. 2) (Miyabe, 1931). This uplift produced a coastal emergence that has been recorded as marine terraces or as emerged littoral bio-constructions (Fig. 3, 4) (Yamasaki, 1926; Tanakadate, 1926). Tsunami heights of up to $12 \mathrm{~m}$ were observed in the coastal area surrounding Sagami Bay, but were somewhat smaller on the Pacific coast of the Boso Peninsula (Fig. 5) (Hatori et al., 1973).

Based on such observational data, a number of fault models have been created for the 1923 Taisho Earthquake along the northern edge of the Philippine Sea Plate (Fig. 6). For example, Ando (1974) inferred a model involving reverse and right-lateral faulting on a low-angle fault plane that strikes along the trough, and Matsu' ura and Iwasaki (1983) proposed an improved model using the then newly-developed inversion analysis method. In 1995, Wald and Somerville discussed a heterogeneous slip-distribution model based on teleseismic data that was later reevaluated by Kobayashi and Koketsu (2005) and Nyst et al. (2006) in the light of new data, even though their conclusions were not significantly different from those of previous models.

\section{Genroku Kanto Earthquake}

While, for obvious reasons, there are no instrumental observation data for the 1703 Genroku Earthquake, historical records and tectonic geomorphology provide useful clues that can be used to recreate data on crustal movements and their resultant tsunami (Fig. 2-5, 7-9).

Matsuda et al. (1974) measured the height of the 1703 shoreline and compared it with the accumulated vertical crustal movements that occurred since the earthquake in order to calculate the pattern of coseismic movements occurring during the 1703 event. However, the results obtained were not fully consistent with what could be deduced from interpretations of historical records. Therefore, Shishikura (2000) and Shishikura and Echigo (2001) reevaluated the distribution of the 1703 shoreline while taking into consideration
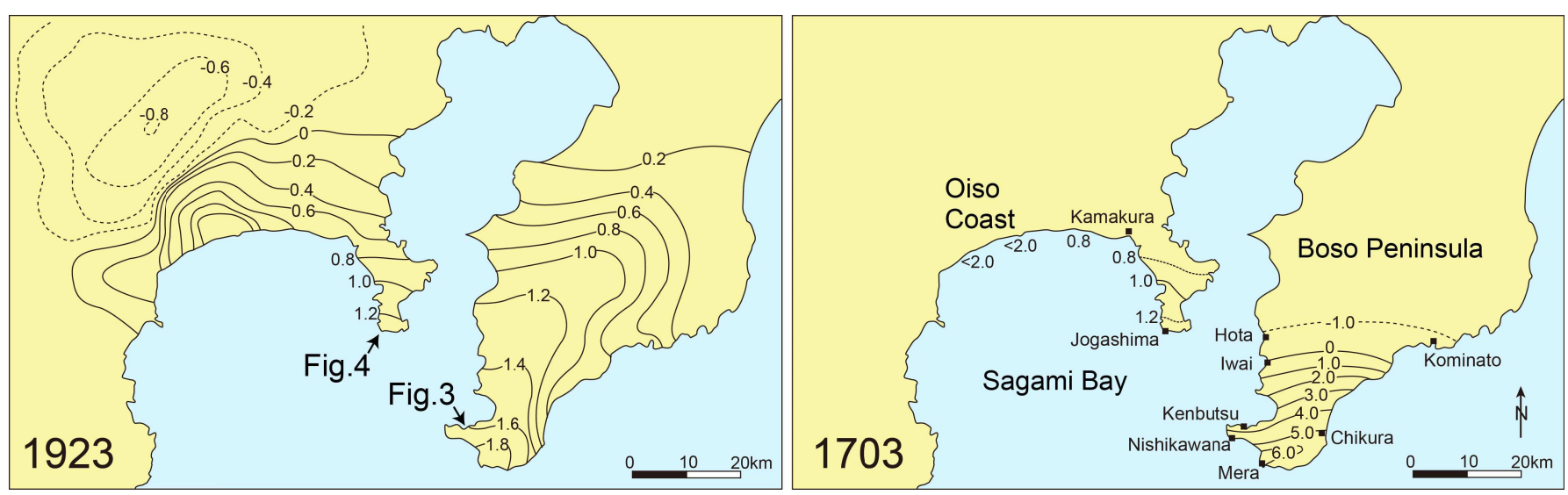

Figure 2. Coseismic vertical crustal movements during the 1703 Genroku and 1923 Taisho Kanto Earthquakes. In the case of the 1703 Genroku Earthquake, data was restored from emerged shoreline features (Shishikura, 2000; Shishikura and Echigo, 2001) and historical records (Usami et al., 1977; Sasou; 2003). In the case of the 1923 Taisho Earthquake, it was based on Miyabe (1930). 


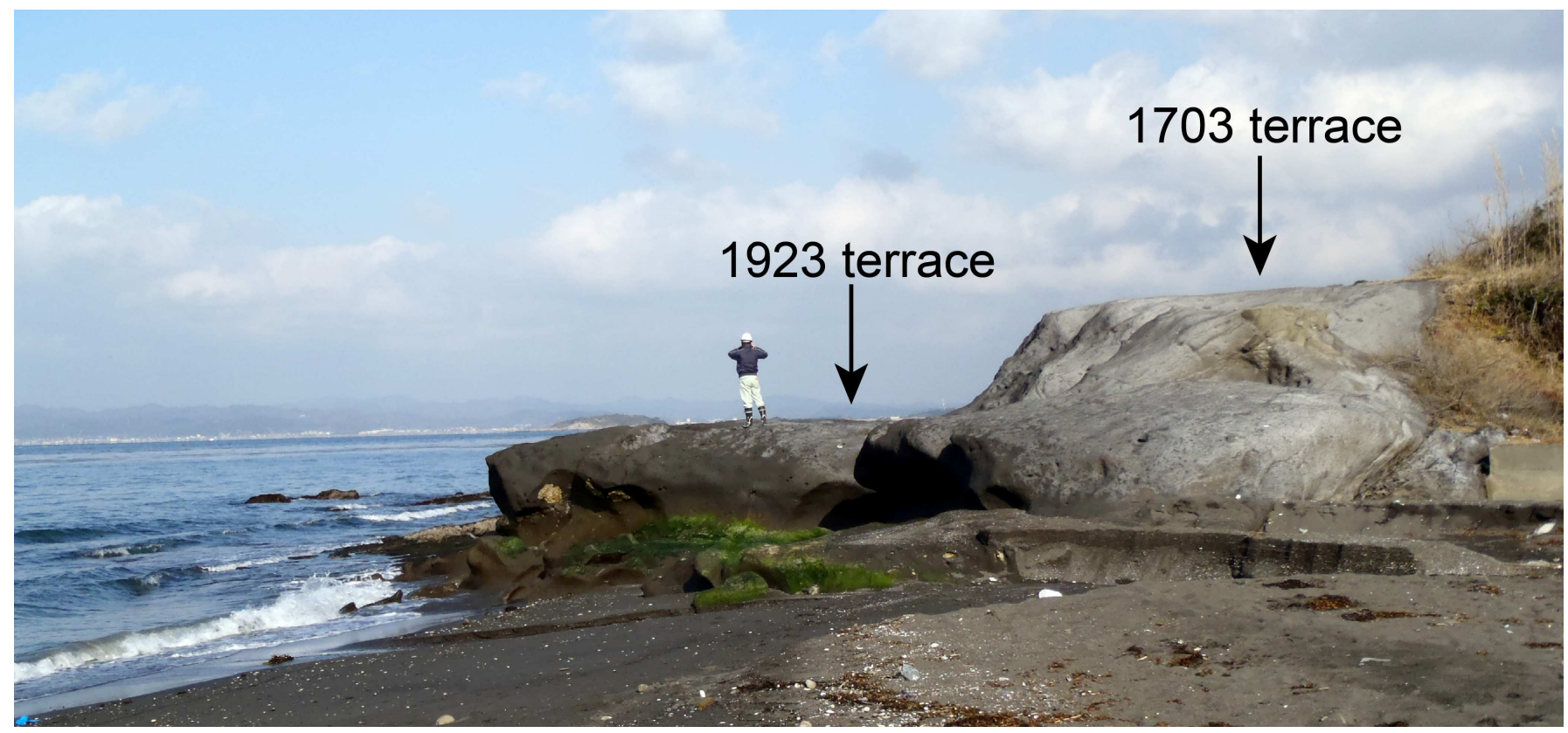

Figure 3. Marine terraces associated with uplifts during the 1703 Genroku and 1923 Taisho Kanto Earthquakes in Kenbustu beach, the southernmost part of the Boso Peninsula. The location is shown in Fig. 2.

historical evidence (Usami et al., 1977), and proposed a renewed coseismic vertical crustal movement model for the 1703 Genroku event. This allowed them to infer that the Miura Peninsula and the Oiso coastal area were uplifted for 1-2 m, as in the 1923 Taisho Kanto Earthquake. In contrast, the Boso Peninsula experienced steep tilting accompanied by an uplift of more than $6 \mathrm{~m}$ in the southernmost part of the cape, and subsidence of at least $1 \mathrm{~m}$ in its central areas (Fig. 2).

Hatori (1975a, 1976) calculated tsunami heights associated with the 1703 earthquake by identifying inundation limits from historical records such as documents and monuments. When compared with the 1923-tsunami limits, it shows that magnitudes were similar around Sagami Bay, but significantly larger along the Pacific coast of the Boso Peninsula (Fig. 5). One of the most divergent points was the inundation distances of up to 2-4 km deep inland from the 1703 shoreline in the strand plain of the Kujukurihama Coast, which were determined based on the locations of memorials erected in remembrance of tsunami victims (Fig. 9) (Koyama, 1987; Namegaya et al., 2011).

Fault models for the 1703 Genroku Earthquake have been proposed from parameters based on the above-mentioned historical and tectonic data (Fig. 10). For example, the model created by Matsuda et al. (1978) using the vertical crustal movement data of Matsuda et al. (1974) involved a series of three thrust faults extending off the Boso Peninsula. Additionally, Aida (1993) proposed a model involving two fault planes that was based on tsunami inversion and the findings of Kasahara (1973), while Murakami and Tsuji (1999) also suggested a three fault plane model extending southeastward. Later, Satake et al. (2008) examined the effect of the fault plane on the eastern side using these models.

More recently, Namegaya et al. (2011) attempted to verify fault models for the 1703 Genroku and 1923 Taisho Earthquakes by establishing fault distributions based on the consolidation of recently accumulated data involving the surface topology of the Philippine Sea Plate (Fig. 11) (e.g. Sato et al., 2005; Tsumura et al., 2009). It is believed that, in the case of the 1923 Taisho Earthquake, the tectonic

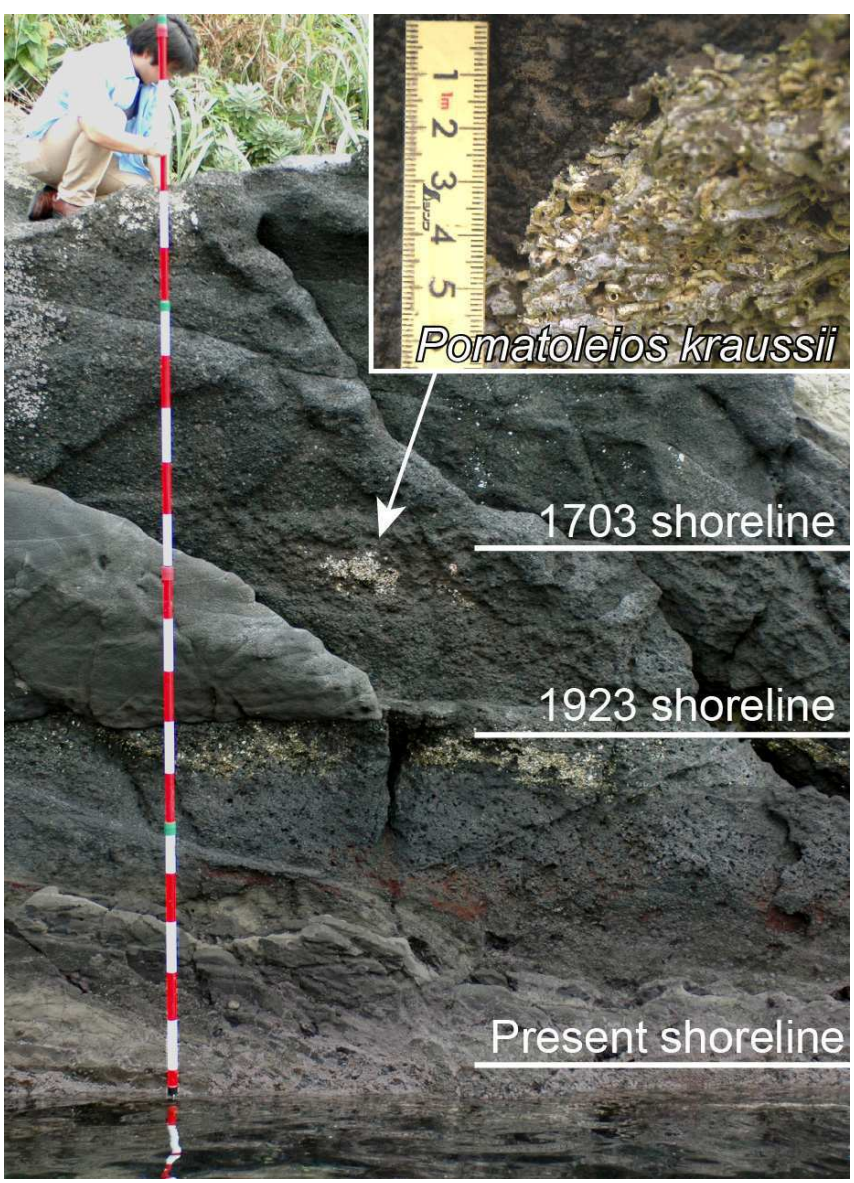

Figure 4. Two levels of emerged sessile assemblages composed primarily of Pomatoleios kraussii, associated with uplifts during the 1703 Genroku and 1923 Taisho Kanto Earthquakes in Jogashima, the southernmost part of the Miura Peninsula. The location is shown in Figure. 2. Revised from Shishikura et al. (2007). 

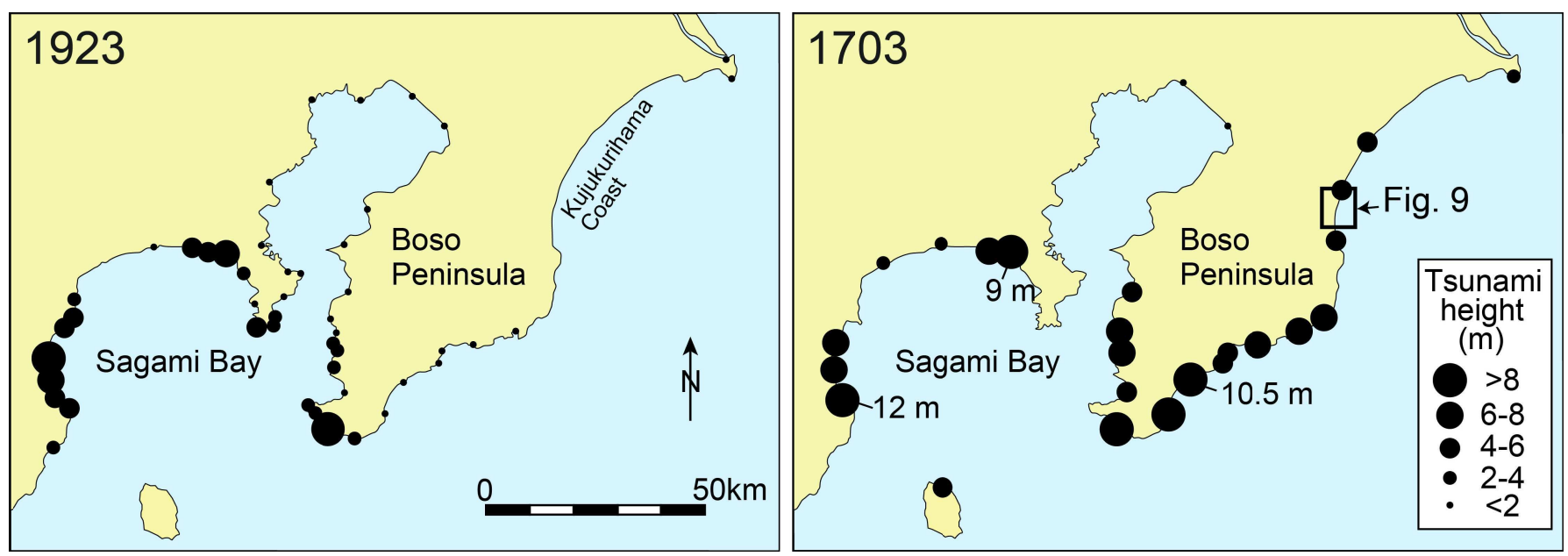

Figure 5. Tsunami heights associated with the 1703 Genroku and 1923 Taisho Kanto Earthquakes in Kanto region. Compiled from Hatori et al. (1973), Hatori (1975a) and Hatori (1976)

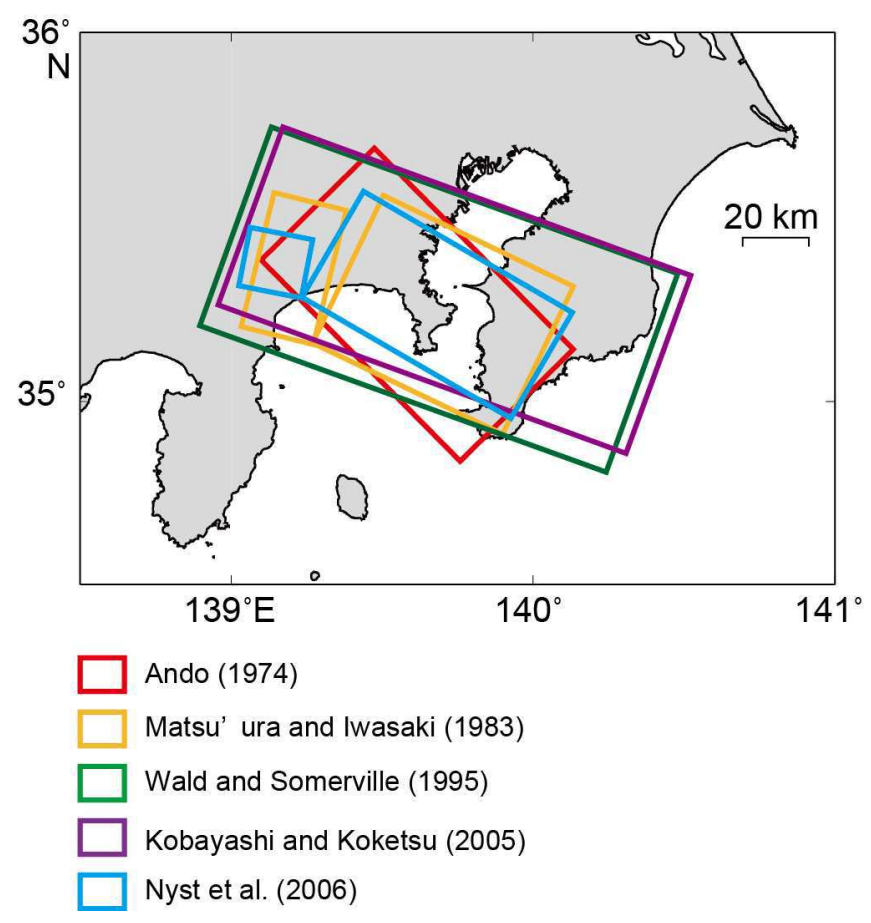

Figure 6. Location of the fault models for the 1923 Taisho Kanto Earthquake

movement primarily entailed a fault rupture near Sagami Bay (Fig. 11A). In the case of the 1703 Genroku Earthquake, this rupture was accompanied by a large fault slip near the southernmost part of the Boso Peninsula (Fig. 11B) of up to approximately $10 \mathrm{~m}$. Tsunami simulations revealed that, in the case of the 1703 Genroku Earthquake, the tsunami-induced inundation starting at the Kujukurihama Coast could not be reproduced without positing a fault off the coast of the Boso Peninsula (Fig. 11C), thereby demonstrating the necessity of an additional offshore fault. However, further research will be needed to determine its position, topography, and slip magnitude of this fault.

\section{Historical earthquakes prior to the 1703 Genroku Kanto Earthquake}

Given the 220-year separation between the 1703 Genroku and
1923 Taisho Earthquakes, and considering the plate convergence rate of 3-4 cm/year (e.g. Seno, 1993), it is estimated that the recurrence interval of earthquakes in the Kanto-region is 200-300 years (e.g. Ishibashi, 1977). However, even though there are no reliable historical earthquake records prior to the 1703 Genroku Earthquake, some candidates have been proposed based on previous studies. For example, the Einin Kanto Earthquake that struck Kamakura in 1293 was associated with massive damage resulting from the strong temblor and tsunami inundation (Ishibashi, 1991), and probable geomorphological/geological evidence of this earthquake has been recorded in the marine terrace of the Boso Peninsula (Shishikura, 1999), as well as tsunami deposits in the Miura Peninsula (Shimazaki et al., 2011).

Recently Kaneko (2012) proposed new interpretations of historical documents related to the existence of the 1495 Meio Kanto Earthquake, which could be considered a predecessor of the 1703 and 1923 earthquakes. This earthquake was previously referred to as the 1498 Meio Tokai Earthquake whose source was inferred to be along the eastern part of the Nankai Trough because historical documents from that period show that some parts of the Kanto region, such as Kamakura and Kominato, had been damaged by a large tsunami during AD 1498 (Hatori, 1975b). However, while some references to a tsunami occurring during the 1495 to 1498 timeframe exist in historical documents, no geomorphological/geological evidence has been found in the Miura and Boso Peninsulas to support them - with the exception of a probable tsunami deposit in Ito City on the Izu Peninsula (Fujiwara et al., 2007). If the plausibility of the 1495 earthquake is accepted, it would indicate a recurrence interval for the historical Kanto earthquake series of approximately 200 years. However, decisive data has not yet been obtained.

\section{Prehistorical earthquakes and tsunamis along the Sagami Trough}

While there were little reliable historical records prior to the 1703 Genroku Earthquake, the region's seismic history has been reconstructed primarily based on analysis of the distribution and the age of Holocene marine terraces and tsunami deposits.

Research focusing on the marine terrace in this area started after the 1923 Taisho Earthquake (Imamura, 1925; Watanabe, 1929). Later, 


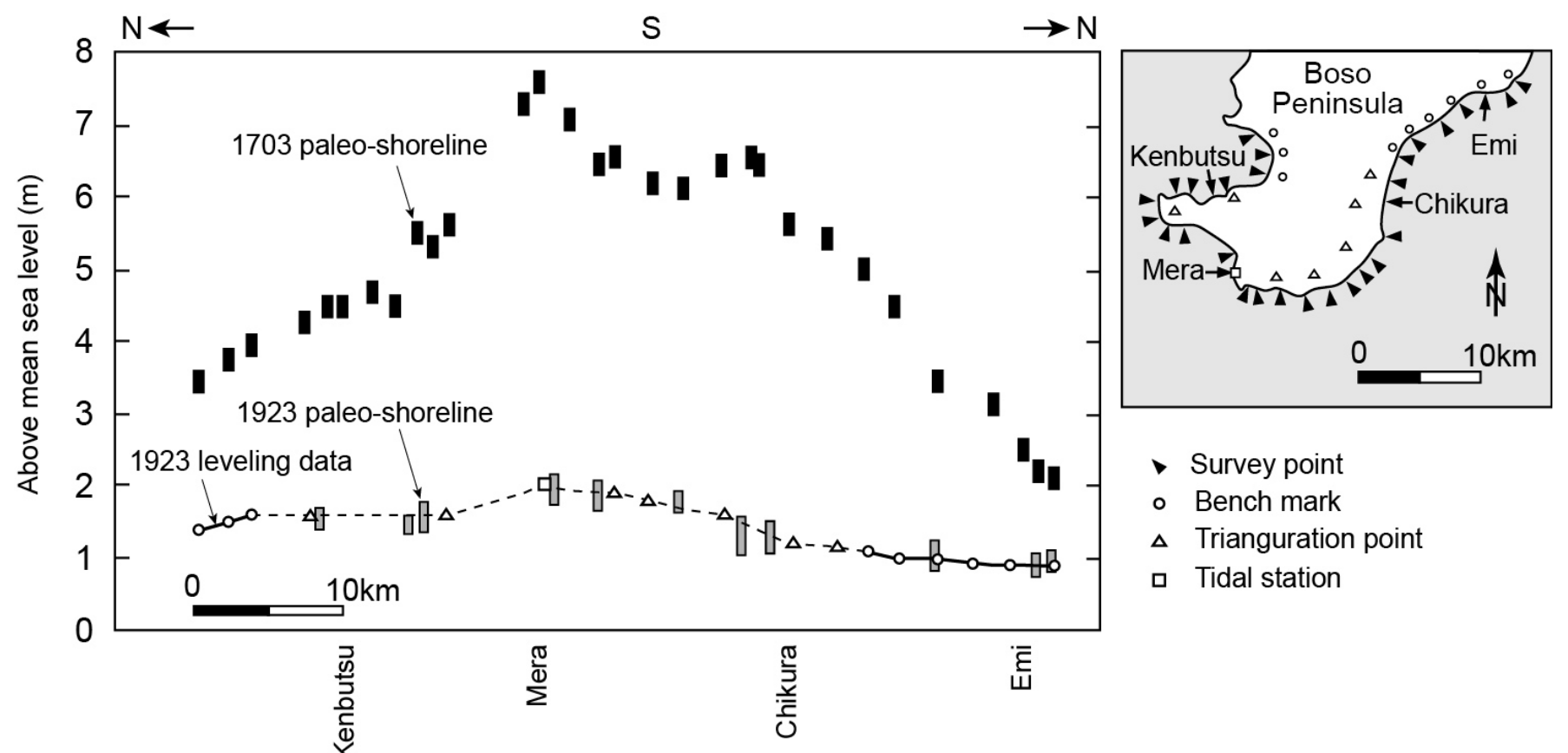

Figure 7. Height distribution of paleoshorelines emerged during the 1703 Genroku and 1923 Taisho Kanto Earthquakes projected along coast of the southern part of the Boso Peninsula. Leveling data related to the 1923 Taisho Earthquake is from re-leveling between (Land Survey Department, 1926).
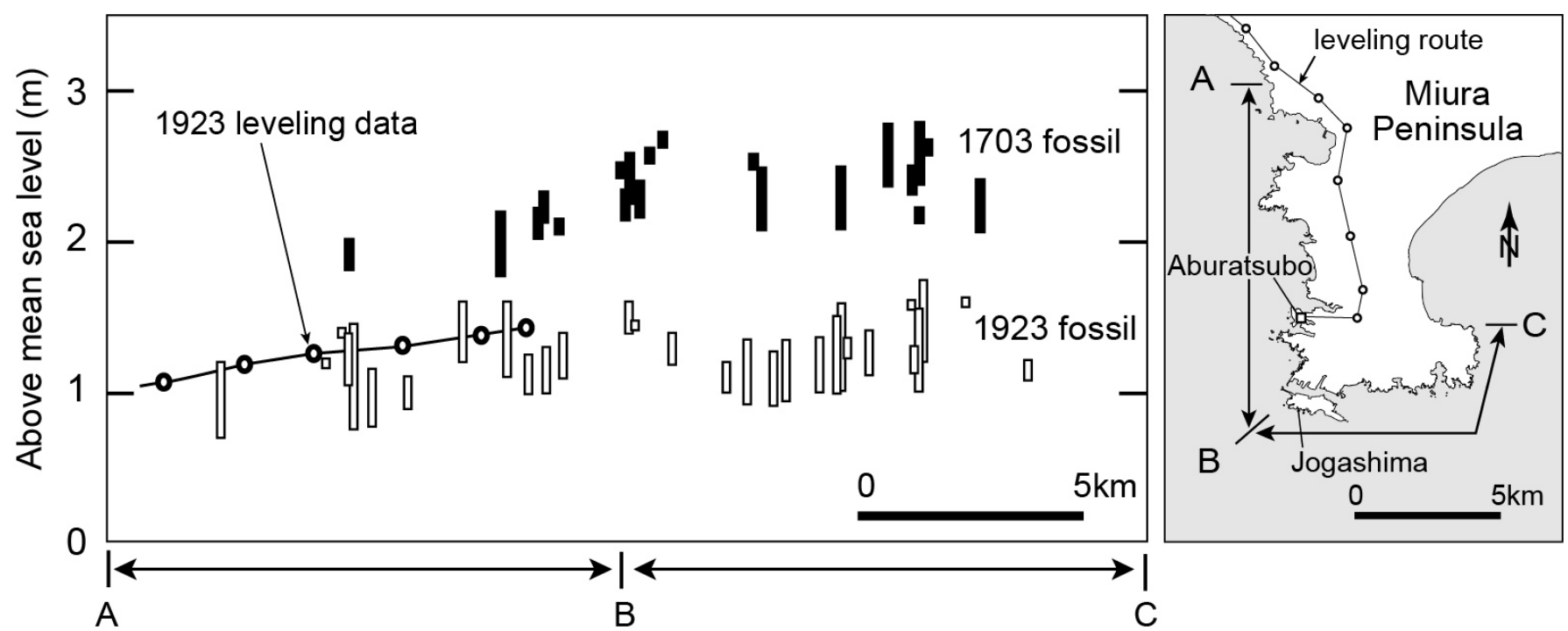

Figure 8. Height distribution of fossil sessile assemblages emerged during the 1703 Genroku and 1923 Taisho Kanto Earthquakes projected along the coast of southern part of the Miura Peninsula. Revised from Shishikura et al. (2007). Leveling data related to the 1923 Taisho Earthquake is from comparison of re-leveling results before and after the earthquake (Land Survey Department, 1926).

Sugimura and Naruse (1954) discovered that the height of the Holocene highest marine terrace was constrained by the accumulation of repeated characteristic uplifts associated with the 1923 earthquake. The terraces, which had raised cumulatively up to $30 \mathrm{~m}$ in altitude in the southernmost part of the Boso Peninsula, can be divided into four separate levels (Fig. 12, 13A) (Matsuda et al., 1974; Yonekura, 1975; Yokota, 1978; Nakata et al., 1980). Nakata et al. (1980) named and radiocarbon-dated them in a stratigraphic descending order as Numa I, which was dated at 7,200 calibrated years before the present (cal yBP), Numa II (5,000 cal yBP), Numa III (3,000 cal yBP) and Numa IV (the Genroku terrace that emerged during AD 1703), respectively. Kayanne and Yoshikawa (1986) clarified that these four wide platforms, including the 1703 terrace, could be sub-divided into several narrow steps around each boundary (Fig. 13(B)). Because the shape of each narrow step is similar to that of the 1923 terrace that was caused by an uplift of 1 to $2 \mathrm{~m}$, it can be conjectured that four great earthquakes, with magnitudes similar to that of the 1703 Genroku Earthquake (Genroku-type), and several earthquakes with magnitudes similar to that of the 1923 Taisho Earthquake (Taishotype), have occurred since 7,200 cal yBP between the Genroku-type megaquakes. Analyzing the emerged beach ridges in the southwestern coast of the Boso Peninsula, at least 11 distinct, Taisho-type earthquake 

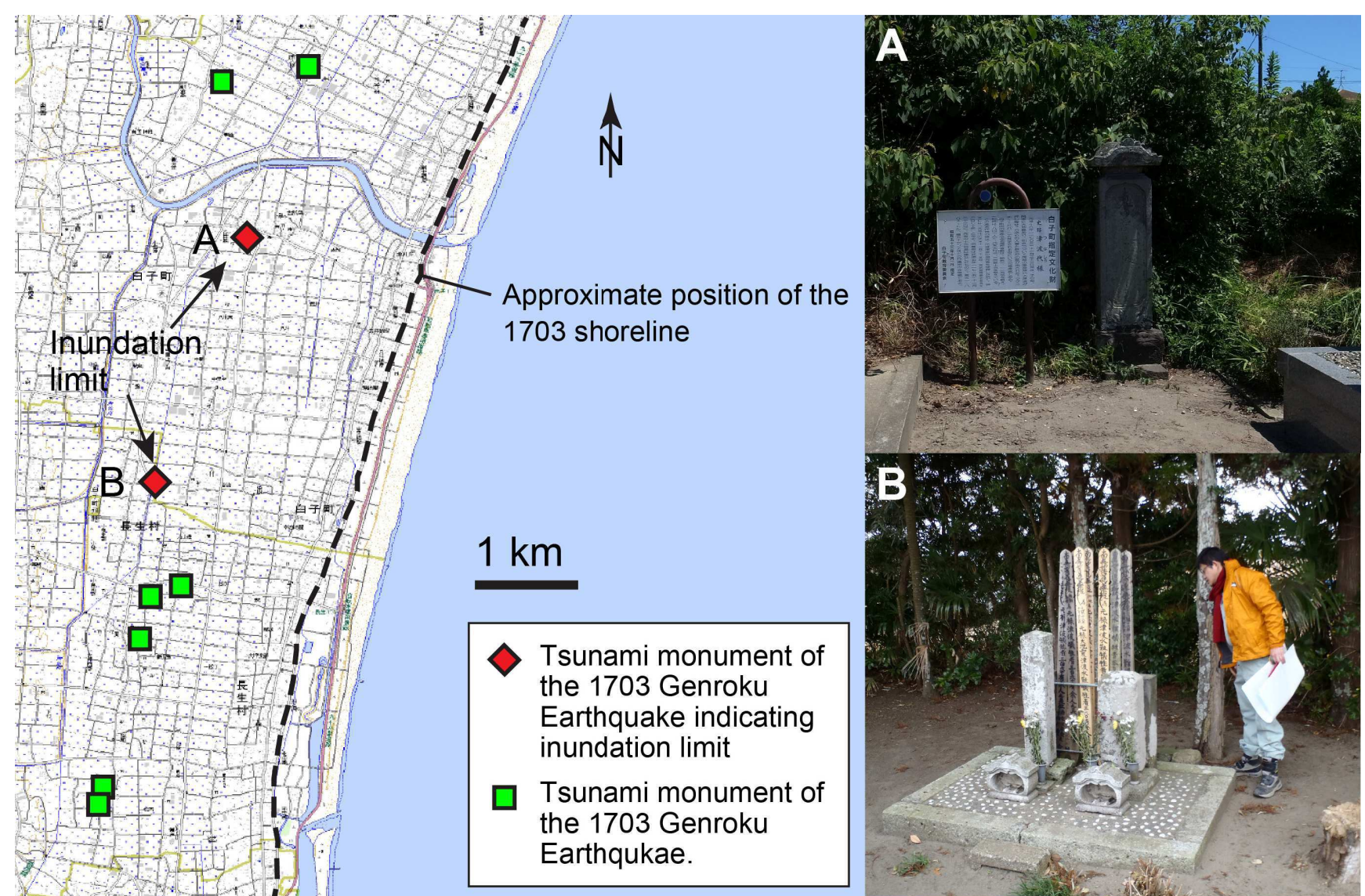

Figure 9. Location and photos of tsunami monuments related to the 1703 Genroku Kanto Earthquake in the Kujukurihama Coast. A: Tsunashirosama, B: Muenzuka-tsunami-seirei-sama. Base map is 1/25,000 topographic map of "Mobara", "Kazusaichinomiya", "Shitengi" and “Torami” published by Geospatial Information Authority of Japan. Location is shown in Figure 5. Revised from Namegaya et al. (2011).

were identified, and their timings were dated from radiocarbon ages as 6,800-6,650 cal yBP, 6,000-5,900 cal yBP, 5,400-5,300 cal yBP, 3,800-3,600 cal yBP, 3,300-3,100 cal yBP, 2,800-2,700 cal yBP, 2,500-2,400 cal yBP, 1,300-1,200 cal yBP and 1,050-650 cal yBP. The latter is believed to be the 1293 Einin Earthquake, and, when

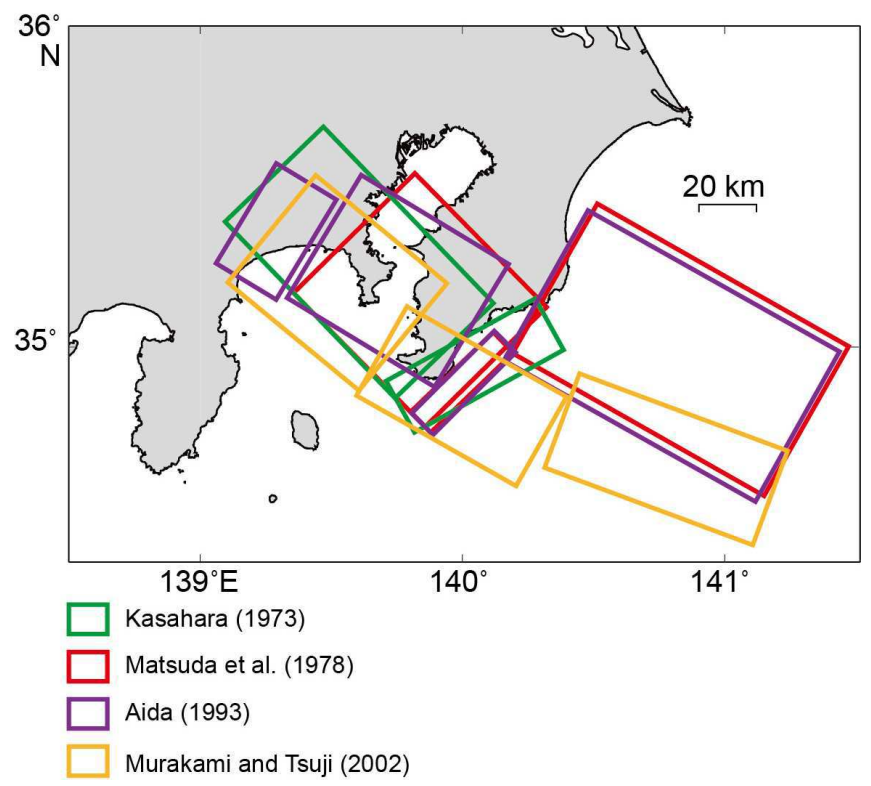

Figure 10. Location of the fault models for the 1703 Genroku Kanto Earthquake taken together with the others on the list, indicates a mean recurrence interval of almost 400 years (Shishikura et al., 2001, 2005).

In the Miura Peninsula, at least three Holocene marine terrace steps of up to $20 \mathrm{~m}$ in altitude have been identified. These were dated to approximately 7,000 cal yBP, 5,200, cal yBP, and 3,400 cal yBP in

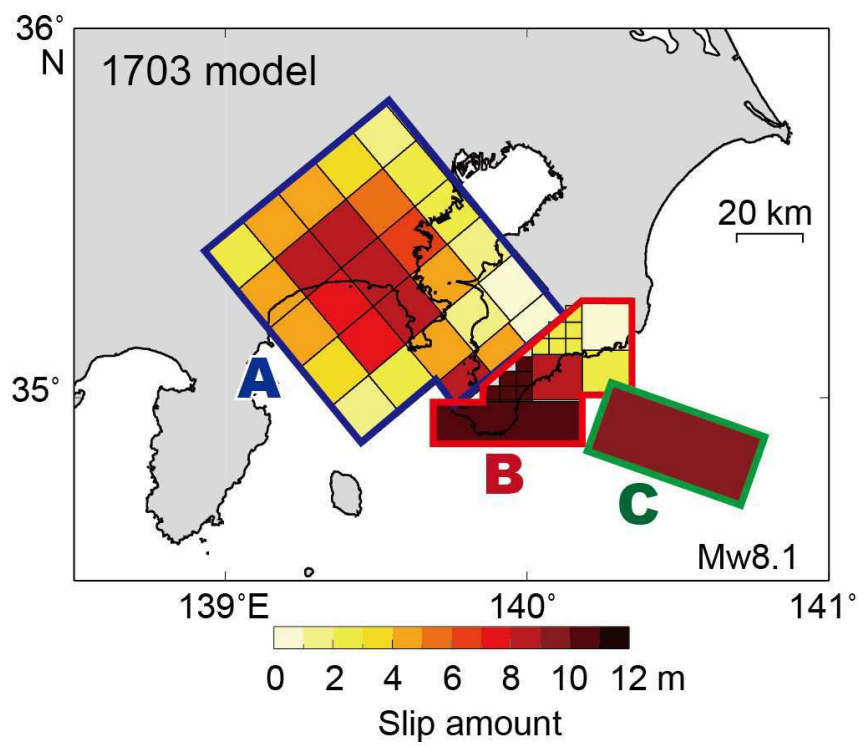

Figure 11. Fault model for the 1703 Genroku Kanto Earthquake taking into consideration the upper plane geometry of the Philippine Sea plate. Revised from Namegaya et al. (2011). 


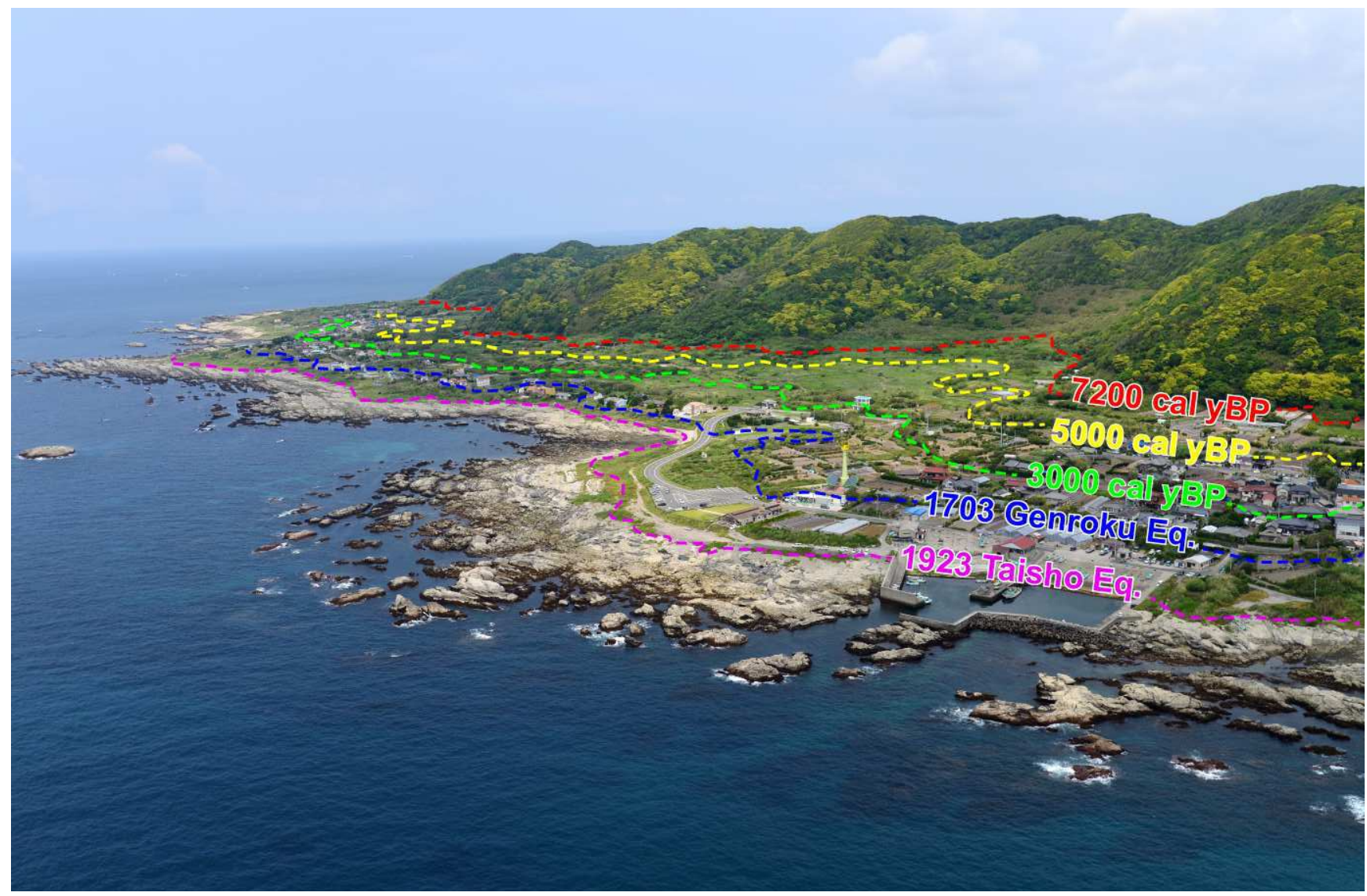

Figure 12. Holocene marine terraces in Nishikawana, the southernmost part of the Boso Peninsula.

descending order (Kumaki, 1985). Sub-divided terraces also were partly identified, but have not yet been dated.

Holocene marine terraces that are partly divided into three or four levels can be identified in the Oiso coast (Kumaki, 1985). Although the height of the highest paleoshoreline reaches $30 \mathrm{~m}$ in altitude or more in some places, the emergence of these terraces may not be related to interplate earthquakes alone. Instead, they may also indicate an active inland fault, such as the Kozu-Matsuda Fault Zone that lies in the western end of the Oiso Coast. This fault zone extends from the Sagami Trough and is inferred to branch from the plate boundary as an imbricate thrust (Sato et al., 2005). However, it does not appear that this fault ruptured during the 1923 earthquake. The results of a trench excavation survey (Kanagawa Prefecture, 2003) reveal that the most recent event occurred between the $12^{\text {th }}$ and early $14^{\text {th }}$ centuries, and probably correlated with the 1293 Einin Earthquake. Note that vertical fault displacement is estimated to be 3.0 to $6.5 \mathrm{~m}$ per event.

The tsunami deposit record in the Miura Peninsula also indicates prehistorical Kanto earthquakes whose timings have been dated to $5,400-5,250 \mathrm{cal}$ yBP, 4,250-3,950 cal yBP, and 2,750-2,600 cal yBP. These dates are consistent with the age of marine terraces (Fujiwara et al., 1999). Older events, before being recorded into marine terraces,

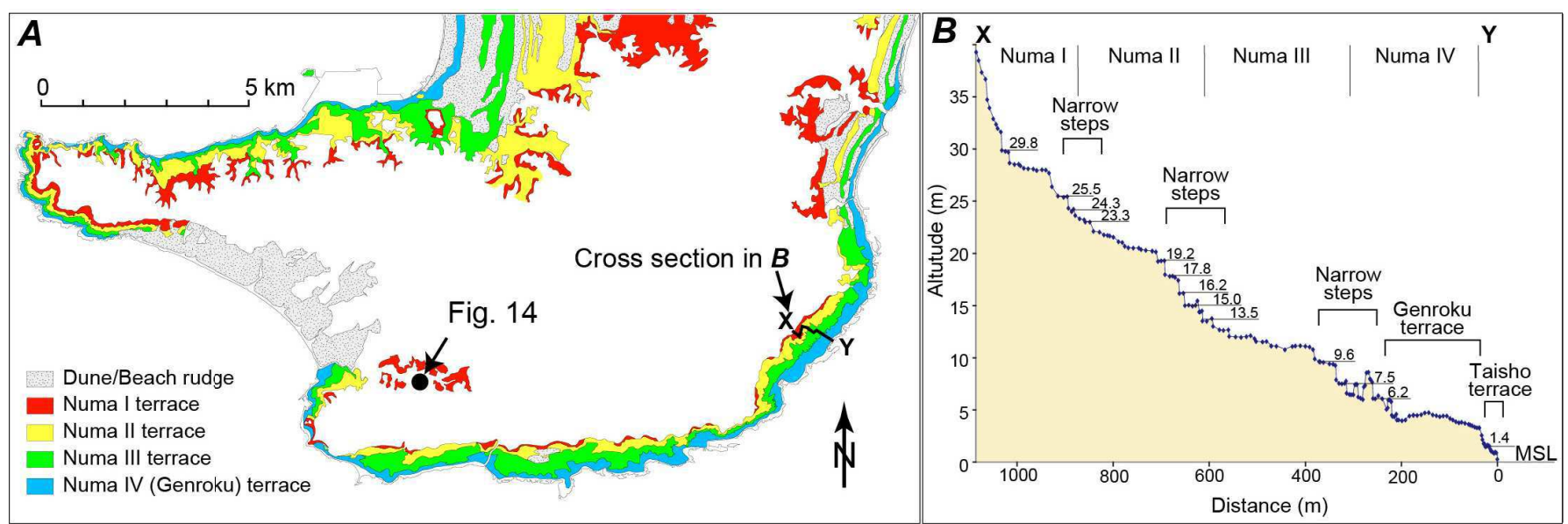

Figure 13. Terrace classification map (A) and measured topographic profile (B) in the southern part of the Boso Peninsula. Revised from Kawakami and Shishikura (2006). 


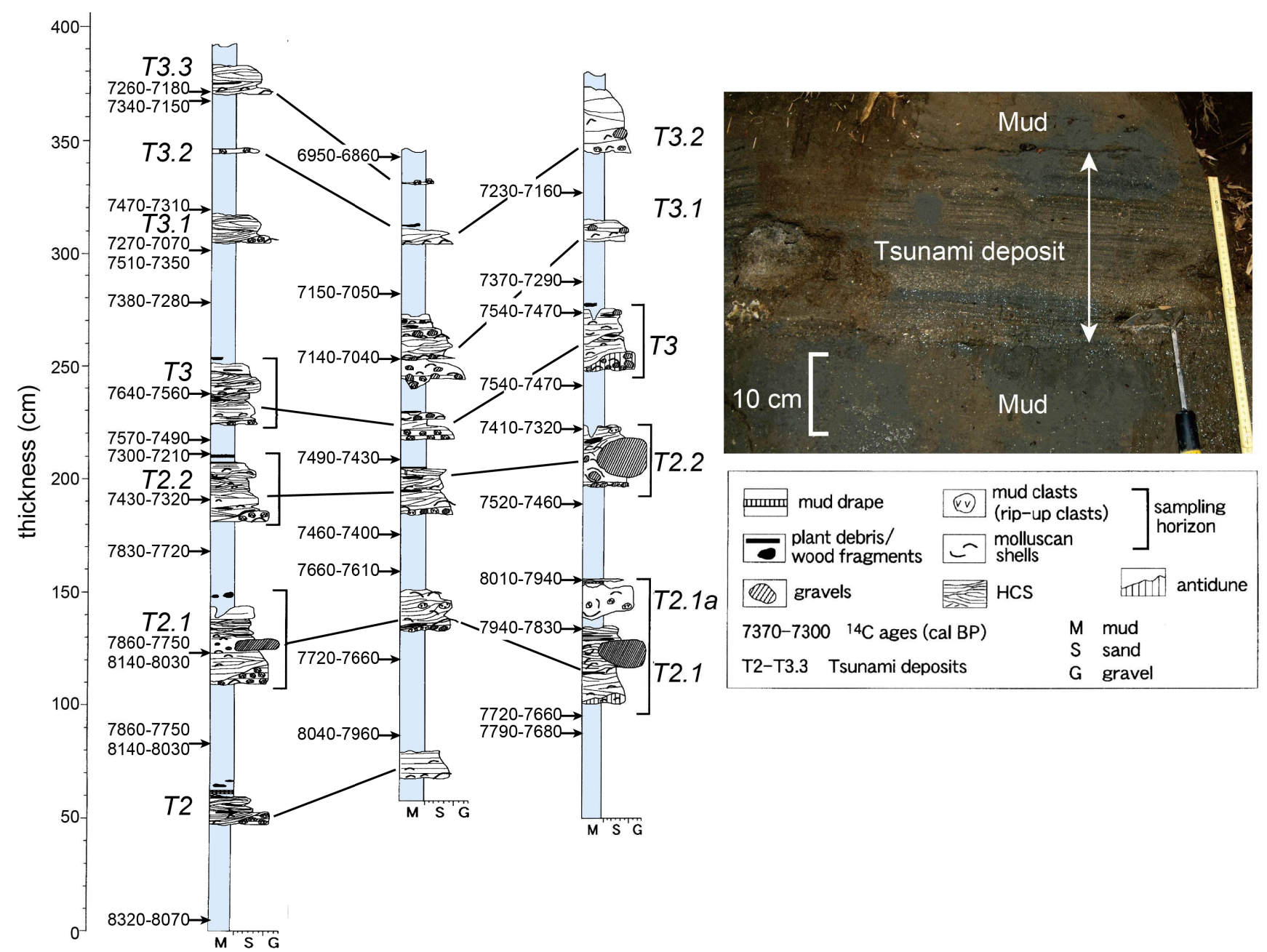

Figure 14. Geological columnar sections and photo in outcrop of the Tomoe River near Mera, southernmost part of the Boso Peninsula. Revised from Fujiwara et al. (2003).

can also be detected from an uplifted postglacial buried valley deposit in the southernmost part of the Boso Peninsula, where at least seven event deposits composed of sand and gravel have been intercalated with inner-bay mud deposited during the period from 8,100 to 7,000 cal yBP, thus suggesting that tsunami events have occurred at intervals of 100 to 300 years (Fig. 14) (Fujiwara and Kamataki, 2007).

Compiling all the age data mentioned above, a rupture history along the Sagami Trough is presented in Fig. 15. Interpretation of the results from a tectonic standpoint has led to the conclusion that the fault in the vicinity of the Sagami Bay (Segment A in Figs. 11 and $15)$, ruptures approximately every 400 years on average, and that the fault near the southernmost part of the Boso Peninsula (Segment B$\mathrm{C}$ in Figs. 11 and 15) undergoes massive slippage every 2,000 to 2,700 years during the Genroku-type earthquake (Shishikura, 2003).

\section{Inconsistencies between geomorphic/ geologic and geodetic data}

According to recent geodetic analysis, the slip-deficit rate of the plate along the Sagami Trough is approximately $20 \mathrm{~mm} / \mathrm{year}$ in the vicinity of the Sagami Bay and $30 \mathrm{~mm} / \mathrm{year}$ near the southernmost part of the Boso Peninsula (Fig. 16) (Sagiya, 2004; Nishimura, 2012). As described in the previous section, based on tectonic

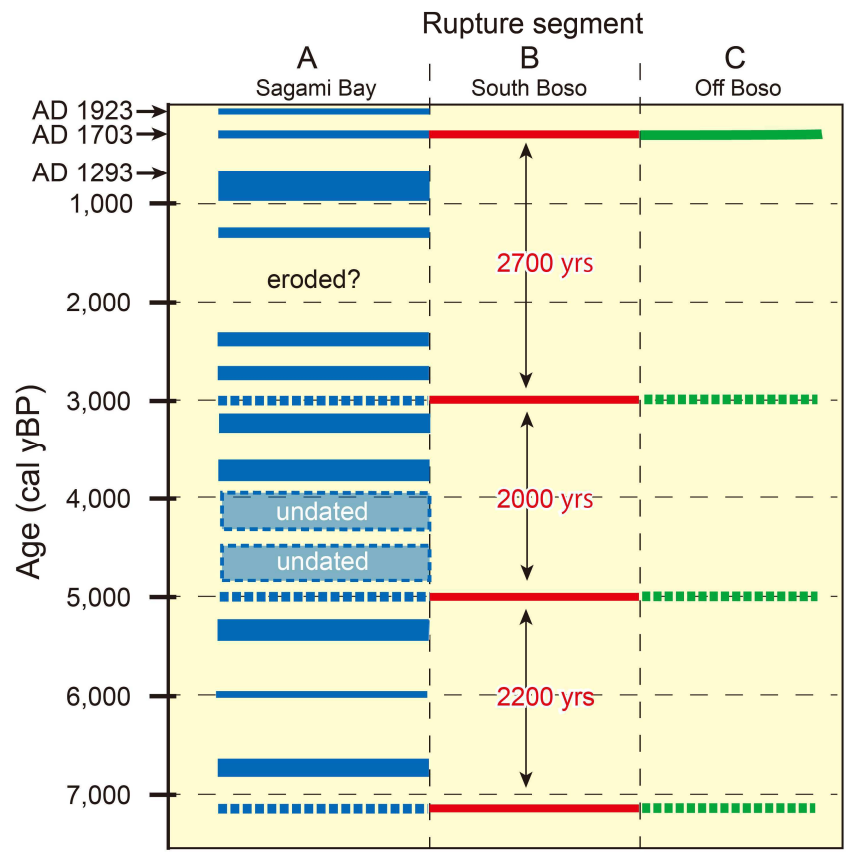

Figure 15. Rupture history of the earthquakes along the Sagami Trough, deduced from the age and distribution of Holocene marine terraces. Compiled from Shishikura et al. (2001, 2005). 


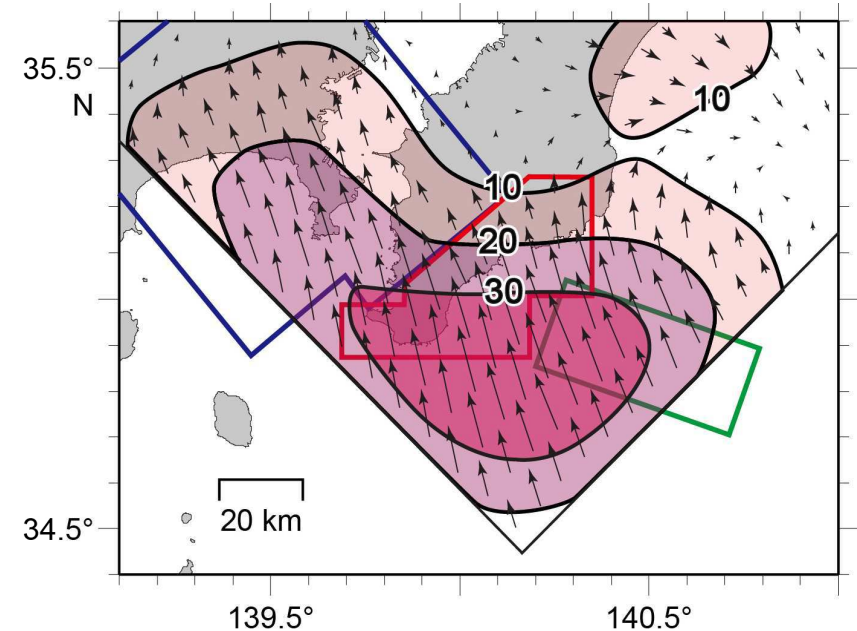

Figure 16. Slip deficit rate in South Kanto deduced from onshore GNSS data between April 1996 and March 2000, and a simplified fault model for the 1703 Genroku Kanto Earthquake. Contours are in millimeters. Slip deficit rate is based on Sagiya (2004). Fault model is from Namegaya et al. (2011).

geomorphological analysis, it is estimated that earthquakes causing rupture of the Segment A (Figs. 11 and 15) in the vicinity of the Sagami Bay occur on an average of approximately every 400 years. If the resulting slip per event is assumed to be in the order of 5 to 10 $\mathrm{m}$, from a geodetic standpoint, it is estimated are 250 to 500 years are required for the accumulation of stress to become sufficient to cause a rupture, resulting in a recurrence interval estimate that is consistent with that of tectonic analysis. Meanwhile, if we assume that the Segment B-C (Figs. 11 and 15) area near the southernmost part of the Boso Peninsula only shifts during the Genroku-type Earthquakes, it should continue to accumulate stress over a longer period of time roughly between 2,000 to 2,700 years. A simple calculation based on the slip-deficit rate yields an estimated accumulated slip amount of 60 to $80 \mathrm{~m}$. However, as explained earlier, the slip amount of the Segment B (Figs. 11 and 15) during the 1703 Genroku Earthquake is believed to have been up to approximately $10 \mathrm{~m}$, which indicates that there is a substantial discrepancy between the geomorphologic and geodetic estimates.

To resolve this problem, at least three hypotheses can be considered. First, because global navigation satellite system (GNSS) observation is very recent technique and its data accumulation covers too short of a period to evaluate a large earthquake cycle, the past slip-deficit rate might actually be variable and could have been slower than present phenomena. Second, if the plate interface sometimes slips more slowly, it can reduce crustal stress. However, the strong coupling area shows both coseismic and aseismic behaviors, which is somewhat physically irrational. Third, if the coseismic ruptures of the Segment B (+C) shown in Fig. 11 and 15 have been occurring at the high frequency rate of once every several hundred years (which overturns the conventional interpretation) the inconsistency in slipdeficit estimates is resolved. This hypothesis will be examined in the next section.

\section{Interpretation based on new tectonic evidence}

Uno et al. (2007) and Endo and Miyauchi (2008) recently conducted a reexamination of the marine terraces in the southern part of the Boso Peninsula, and concluded that the coastal uplift timing of the western side did not necessarily coincide with that of the eastern side, as had been previously believed. The previous conventional interpretation had been that Genroku-type earthquakes resulting in substantial coastal uplifts of the entire southernmost part of the peninsula recurred at intervals of 2,000 to 2,700 years. However, the varying coastal uplift timing of the western and eastern sides suggests that different earthquakes on each coast caused the uplifts. In terms of the 1703 Genroku Earthquake fault model, it appears that there may be a third type of earthquake that only produces the ruptures of the Segment B, and, in some cases, part of the Segment C. The inconsistency in slip-deficit estimates described in the previous section can be resolved if this type of earthquake is assumed to occur at a frequency of every several hundred years. More specifically, the tsunami deposit record mentioned in previous section indicating that high-frequency tsunami events occur near the southernmost part of the Boso Peninsula may, in fact, constitute a combined record of tsunamis resulting from these different earthquake types.

The two recent studies reviewed in the beginning of this section reported only four to six marine terraces levels in the eastern side, which does not seem to indicate frequent Segment B type ruptures. However, as described in Figure 13(B), the marine terrace geometry actually shows at least 15 levels, with various scale step combinations. Since it is difficult to explain this marine terrace geometry using just three earthquake types, as defined from a simple combination of the three segments shown in figures 11 and 15 , the past uplift events should be re-classified based on a reinterpretation of the marine terrace distribution.

Furthermore, Holocene marine terraces are found to exist along the eastern coast of the Boso Peninsula extending up to the Kujukurihama Coast where no historical coseismic uplift, including the 1923 Taisho and 1703 Genroku Earthquakes, has been observed (Fig. 17) (Shishikura, 2001). For example, the Holocene highest foreshore deposit dated around 6,000 years ago is seen raised to $9.6 \mathrm{~m}$ in Mobara (Fig. 17A), and some geophysical simulation studies for long-term crustal deformation have proposed that such uplift could also be made by steady plate motion at a subduction zone (e.g., Hashimoto et al., 2004). Although a part of the cumulative uplift component may include such aseismic motion, the existence of several emerged wave-cut-bench levels suggests an intermittent uplift with amounts of at least $1 \mathrm{~m}$ per event (Fig. 17B).

Masuda et al. (2001) also reported the repeated occurrence of intermittent coastal uplift events deduced from the height distribution of inter-tidal deposit in the southern part of the Kujukurihama Coast. These observations suggest that it may be necessary to consider the existence of yet more uplift-causing earthquake types in this coastal region. For example, it may be necessary to consider an even deeper plate interface rupture occurring further north than the area covered by the fault model shown in figure 11, or the possibility that an offshore active fault may exist in the North American Plate near the Boso Peninsula.

\section{Future research}

The new interpretation presented here is based on limited data, and, as such, remains in the realm of a working hypothesis. In order to verify the existence of the other earthquake types, it will be necessary to conduct a more detailed investigation of marine terraces along the 


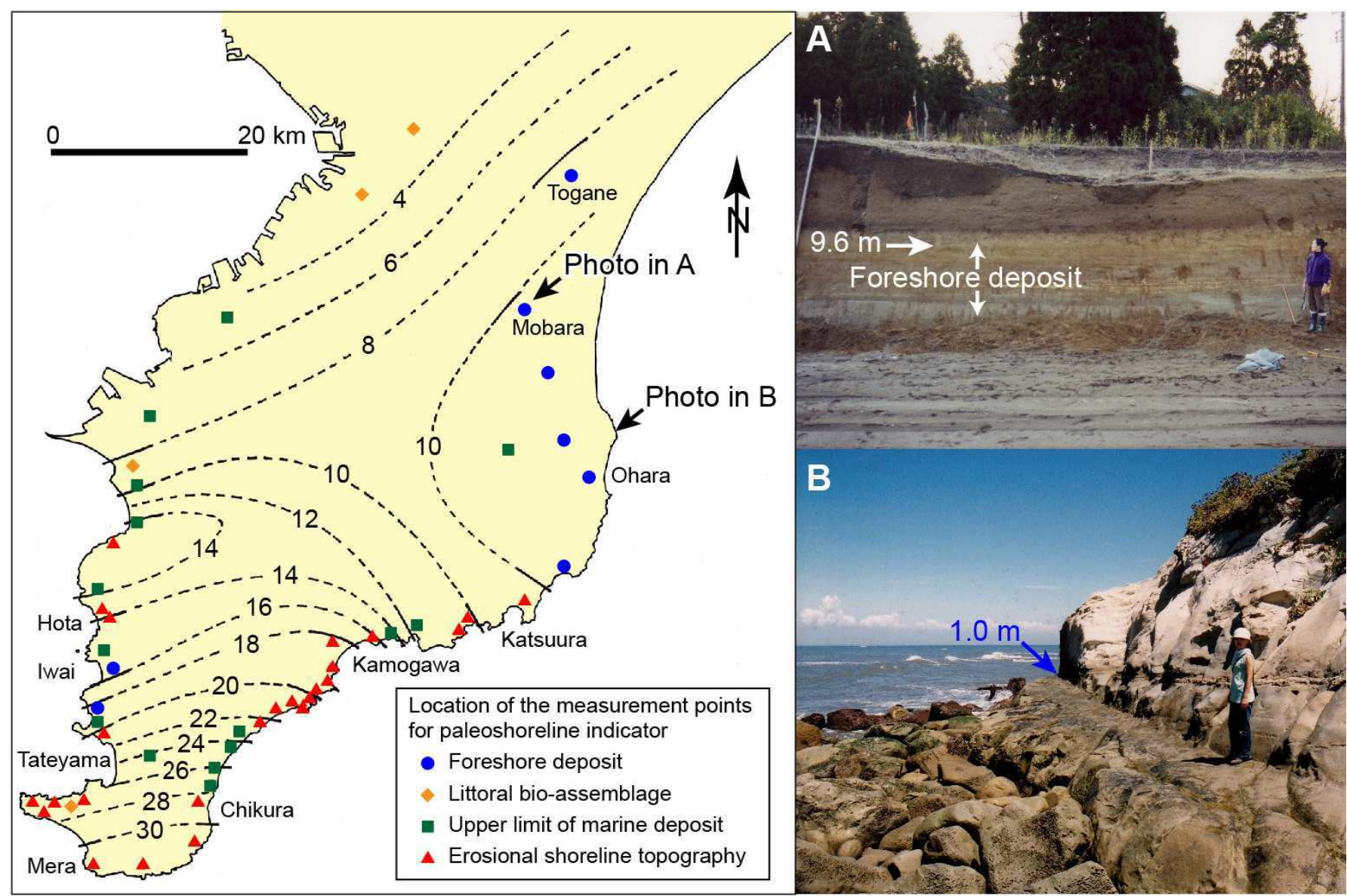

Figure 17. Height distribution of the Holocene highest marine terrace in the Boso peninsula and photos of marine terrace in the eastern part of the Boso Peninsula. Contours are in meters. Revised from Shishikura (2001)

southern and eastern shorelines of the Boso Peninsula. If we are able to identify a specific terrace and trace it over a wide area along the coast, we might be able to reproduce the sequence of uplift events, and would then be able to approximately verify the fault slip distribution.

As we are currently unable to assess the tectonic movement off the coast of the Boso Peninsula (Fig. 15C) based on marine terraces, we must verify the seismic history of the area based on tsunami deposit records and seismic turbidite sequences, such as Kawamura et al. (2014). However, more progress will be necessary in areas other than geomorphological/geological surveys. It will also be necessary to make progress in geophysical simulation studies by incorporating geodetical observations such as those made in Noda et al. (2013) in order to understand the relationship between the plate motions of the Sagami Trough and the variety of large earthquakes.

\section{Acknowledgements}

I would like to thank Prof. Yildirim Dilek, Dr. Kiichiro Kawamura, and the anonymous reviewer for their useful comments and suggestions to improve this paper. I also thank Prof. Yujiro Ogawa for his encouragement and for providing me the opportunity to submit this paper.

\section{References}

Aida, I., 1993, Historical tsunamis and their numerical models which occurred in the north-western part of Sagami Bay, J. Geogr. (Chigaku zasshi), v. 102, pp. 427-436, (in Japanese with English abstract and figure captions). Ando, M., 1974, A fault-origin model of the great Kanto earthquake of 1923 as deduced from geodetic data. Bull. Earthq. Res. Inst. Univ. Tokyo, v. 49 , pp. 19-32.

Bird, P., 2003, An updated digital model of plate boundaries, Geochemistry Geophysics Geosystems, v. 4 (3), 1027, doi:10.1029/2001GC000252.

Cabinet Office, 2013, Report on seismic source models, seismic intensity distributions and tsunami heights for the M7 class earthquake in the capital and the M8 class earthquake along the Sagami trough, 45p. (in Japanese).

Earthquake Research Committee, 2014, Long term evaluation of seismic activities along the Sagami Trough (second edition), 81p. (in Japanese).

Endo, K. and Miyauchi, T., 2011, Reexamination in ages and altitudes of Holocene emergent coastal geomorphology associated with seismotectonics along the Sagami Trough, Japan, Abstract of Japanese Society for Active Fault Studies 2011 Fall Meeting, P-06 (in Japanese).

Fujiwara, O., Masuda, F., Sakai, T., Irizuki, T. and Fuse, K., 1999, Holocene tsunami deposits detected by drilling in drowned valleys of the Boso and Miura Peninsulas, The Quat. Res. (Daiyonki-Kenkyu), v. 38, pp. 41-58 (in Japanese with English abstract and figure captions).

Fujiwara, O. and Kamataki, T., 2007, dentification of tsunami deposits considering the tsunami waveform: an example of subaqueous tsunami deposits in Holocene shallow bay on southern Boso Peninsula, central Japan, Sedimentary Geology, v. 200, pp. 295-313.

Fujiwara, O., Hirakawa, K., Kaneko, H. and Sugiyama, H., 2007, Tsunami (?) event deposit observed in the Usami site, northern part of Ito City, Shozuoka Prefecture, Research Reports of Tsunami Engineering, v. 24, pp. 77-83 (in Japanese).

Hashimoto, C., Fukui, K. and Matsu'ura, M., 2004, 3-D Modelling of Plate 
Interfaces and Numerical Simulation of Long-term Crustal Deformation in and around Japan, PAGEOPH, v. 161, pp. 2053-2068.

Hatori, T., Aida, I. and Kajiura, K., 1973, Tsunamis in the South-Kanto district, in Publications for the 50th Anniversary of the Great Knato Earthquake, pp. 57-66, Earthquake Res. Inst., Tokyo, (in Japanese with English abstract).

Hatori, T., 1975a, Monuments of the tsunami of 1703 and 1923 in the SouthKanto district, Bull. Earthq. Res. Inst. Univ. Tokyo, v. 50, pp. 385-395, (in Japanese with English abstract and figure captions).

Hatori, T., 1975b, Sources of large tsunamis generated in the Boso, Tokai and Nankai regions in 1498 and 1605, Bull. Earthq. Res. Inst. Univ. Tokyo, v. 50, pp. 171-185, (in Japanese with English abstract and figure captions).

Hatori, T., 1976, Monuments of the 1703 Genroku tsunami along the south Boso Peninsula: wave height of the 1703 tsunami and its comparison with the 1923 Kanto tsunami Bull. Earthq. Res. Inst. Univ. Tokyo, v. 51, pp. 63-81, (in Japanese with English abstract and figure captions).

Imamura, A., 1925, Report on the great Kanto earthquake, Rep. Imp. Earthquake Invest. Comm. 100A, pp. 21-65, (in Japanese).

Ishibashi, K., 1977, Source region of the 1703 Genroku Kanto Earthquake and recurrence time of major earthquakes in Sagami Bay, Japan (1), J. Seismol. Soc. Jpn. (Zishin), v. 53, pp. 357-372, (in Japanese with English figure captions).

Ishibashi, K., 1991, The 1293 Einin Kamakura earthquake and the recurrence time of great interplate earthquakes along the Sagami Trough, central Japan, Abstract of 1991 Fall Meeting Seismol. Soc. Jpn., Tokyo, (in Japanese).

Kanagawa Prefecture, 2003, Survey result report of the Kannawa/KozuMatsuda Fault Zone, 78p, (in Japanese)

Kaneko, H., 2012, Tsunami deposit detected at the Usami site and reevaluation of the 1495 Meio earthquake and tsunami, Ito shi-shi kenkyu (Research reports of history in Ito city), v. 10, pp. 102-124, (in Japanese).

Kasahara, K., J. Yamada and M. Ando, 1973, Crustal movements in the South Kanto district, and a related working hypothesis: Publications for the 50th anniversary of the great Kanto earthquake, Earthq. Res. Inst. Univ. Tokyo, pp. 103-116, (in Japanese with English abstract and figure captions).

Kawakami, S. and Shishikura, M., 2006, Geological Map 1:50,000. Tateyama, Geological Survey of Japan, (in Japanese with English caption).

Kawamura, K. Nakajima, A., Saito, S., Murayama, M., Shishikura, M., Muraoka, S., Yamamoto, F., Oishi, M. and Kanamatsu, T., 2014, Sedimentation process associated with the Kanto earthquakes along the Philippine Sea plate subduction zone, central Japan: A case study on submarine paleoseismology, Episodes, in this issue.

Kayanne, H. and Yoshikawa, T., 1986, Comparative study between present and emergent erosional landforms on the southeast coast of Boso Peninsula, central Japan. Geogr. Rev. Japan, Ser. A, v. 59, pp. 18-36, (in Japanese with English abstract and figure captions).

Kobayashi, R. and Koketsu, K., 2005. Source process of the 1923 Kanto earthquake inferred from historical geodetic, teleseismic, and strong motion data, Earth Planets and Space, v. 57, pp. 261-270.

Koyama, Y., 1987, Document of the Genroku tsunami in the Kujukuri area, Monthly Earth (Gekkan Chikyu), v. 94, no. 4, pp. 188-194, (in Japanese).

Kumaki, Y., 1985, The deformations of Holocene marine terraces in southern Kanto, central Japan, Geogr. Rev. Jpn. Ser. B, v. 58, pp. 49-60.

Land Survey Department, 1926, The change of elevation of land caused by the great earthquake of September 1st, 1923. Bull. Earthq. Res. Inst.Univ. Tokyo, v. 1, pp. 65-68.

Masuda, F., Fujiwara, O., Sakai, T. and Araya, T., 2001, Relative sea-level changes and co-seismic uplifts over six millennia, preserved in beach deposits of the Kujukuri strand plain, Pacific coast of the Boso Peninsula, Japan, J. Geogr. (Chigaku zasshi), v. 110, pp. 650-664, (in Japanese with English abstract and figure captions).

Matsuda, T., Y. Ota, M. Ando and N. Yonekura, 1974, Geological study for the 1703 Genroku Earthquake. In Kakimi, T. and Y. Suzuki, (edu.), Earthquakes and crustal deformation in the Kanto district, pp. 175-192,
Lattice, Tokyo 2, 79p., (in Japanese).

Matsuda, T., Y. Ota, M. Ando and N. Yonekura, 1978, Fault mechanism and recurrence time of major earthquakes in southern Kanto district, Japan, as deduced from coastal terrace data. Geol. Soc. Am. Bull., v. 89, pp. 1610-1618.

Matsu'ura, M. and T. Iwasaki, 1983, Study on coseismic and postseismic crustal movements associated with the 1923 Kanto earthquake. Tectonophysics, v. 97, pp. 201-215.

Miyabe, N., 1931, On the vertical earth movements in Kwanto districts, Bull. Earthquake Res. Inst. Tokyo Univ. $\bullet$ v. 9•Cpp. 1-21.

Moroi, T. and Takemura, M., 2004, Mortality Estimation by Causes of Death Due to the 1923 Kanto Earthquake, Journal of JAEE, v. 4, no. 4, pp. 2145, (in Japanese with English abstract).

Murakami, Y. and Tsuji, Y., 2002, Seismic fault model of the Genroku Kanto Earthquake (31, Dec., 1703) considering with tsunami records, Monthly Ocean -extra issue- (Gekkan Kaiyo Gogai), No. 28, pp. 168-175, (in Japanese).

Nakata, T., Koba, M., Imaizumi, T., Jo, W., Matsumoto, H. and Suganuma, T., 1980, Holocene marine terraces and seismic crustal movements in the southern part of Boso Peninsula, Kanto, Japan. Geogr. Rev. Japan, Ser. A, v. 53, pp. 29-44, (in Japanese with English abstract and figure captions).

Namegaya, Y., Satake, K. and Shishikura, M., 2011, Fault models of the 1703 Genroku and 1923 Taisho Kanto earthquakes inferred from coastal movements in the southern Kanto area, Annual Report on Active Fault and Paleoearthquake Researches, v. 11, pp. 107-120, (in Japanese with English abstract and figure captions).

Nishimura, T., 2012, Interseismic deformation and interplate coupling in southern Kanto, Report of CCEP, v.88, pp. 521-525, (in Japanese with English figure captions).

Noda, A., Hashimoto, C., Fukahata, Y. and Matsu'ura, M., 2013, Interseismic GPS strain data inversion to estimate slip-deficit rates at plate interfaces: application to the Kanto region, central Japan, Geophy. Jour. Int., v. 193, pp. 61-77, doi: 10.1093/gji/ggs129.

Nyst, M., Pollitz, F. F., Nishimura, T. and Thatcher, W., 2006, The 1923 Kanto earthquake reevaluated using a newly augmented geodetic data set, Jour. Geoph. Res., 111, B11306, doi:10.1029/2005JB003628.

Sagiya, T., 2004, Interplate coupling in the Kanto District, central Japan, and the Boso Silent earthquake in May 1996, Pure Appl. Geophys., v. 161, pp. 11-12, 2601-2616.

Satake, K., Shishikura, M., Namegaya, Y., Fuji, R. and Takeuchi, H., 2008, Fault models of the Genroku (1703) Kanto Earthquake and Tsunami along the eastern coast of Boso Peninsula, Historical Earthquakes v. 23, pp. 81-90, (in Japanese with English abstract).

Sato, H., H. Hirata, K. Koketsu, D. Okaya, S. Abe, R. Kobayashi, M. Matsubara, T. Iwasaki, T. Ito, T. Ikawa, T. Kawanaka, K. Kasahara and S. Harder (2005), Earthquake source fault beneath Tokyo, Science, v. 309, pp. 462-464.

Seno, T., 1993, A model for the motion of the Philippine Sea Plate consistent with NUVEL-1 and geological data, Jour. Geoph. Res., v. 98, pp. 17,94117,948 .

Shimazaki, K, Kim, H. Y., Chiba, T., and Satake, K., 2011, Geological evidence of recurrent great Kanto earthquakes at the Miura Peninsula, Japan, Jour. Geoph. Res., 116, B12408, doi:10.1029/2011JB008639.

Shishikuira, M., 1999, Holocene marine terraces and seismic crustal movements in Hota lowland in the southern part of the Boso Peninsula, central Japan, The Quat. Res. (Daiyonki-Kenkyu), v. 38, pp. 17-28, (in Japanese with English abstract).

Shishikuira, M., 2000, Coseismic vertical displacement in the Boso Peninsula during the 1703 Genroku Kanto Earthquake, deduced from emerged shoreline topography, Historical Earthquakes (Rekishi Jishin), v. 16, pp. 113-122, (in Japanese with English abstract).

Shishikuira, M., 2001, Crustal movements in the Boso Peninsula, analyzing the height distribution of Holocene highest paleo-shoreline, Annual Report on Active Fault and Paleoearthquake Researches, v. 1, pp. 273-285, (in Japanese with English abstract and figure captions). 
Shishikura, M., 2003, Cycle of interplate earthquake along the Sagami Trough, deduced from tectonic geomorphology, Bull. Earthquake Res. Inst. Tokyo Univ. $\bullet$ v. $78 \cdot$ Cpp. $245-254$, (in Japanese with English abstract and figure captions).

Shishikura, M. and Echigo, T., 2001, Coseismic vertical displacement during the 1703 Genroku Kanto earthquake in the southern part of the Miura Peninsula, analyzing height distribution of emerged wave-cut benches and fossilized sessile assemblages, Historical Earthquakes (Rekishi Jishin), v. 17, pp. 32-38, (in Japanese with English abstract).

Shishikura, M., Haraguchi, T. and Miyauchi, T., 2001, Timing and recurrence interval of the Taisho-type Kanto Earthquake, analyzing Holocene emerged shoreline topography in the Iwai Lowland, the southwestern part of the Boso Peninsula, central Japan, J. Seismol. Soc. Jpn. (Zishin), v. 53, pp. 357-372, (in Japanese with English abstract and figure captions).

Shishikura, M., Kamataki, T., Takada, K., Suzuki, K. and Okamura, Y., 2005, Survey report of emerged beach ridges in the southwestern part of Boso Peninsula-Timing of the Taisho-type Kanto earthquake-, Annual Report on Active Fault and Paleoearthquake Researches, v. 5, pp. 51-68, (in Japanese with English abstract and figure captions).

Shishikura, M., Echigo, T.and Kaneda, H., 2007, Marine reservoir correction for the Pacific coast of central Japan using $14 \mathrm{C}$ ages of marine mollusks uplifted during historical earthquakes, Quaternary Research, v. 67, pp. 286-291.

Sugimura, A. and Naruse, Y., 1954, Changes in sea level, seismic upheavals, and coastal terraces in the Southern Kanto Region, Japan (I), Jap. Jour. Geol. Geogr., v. 24, pp. 101-113.

Tanakadate, S., 1926, The Kanto earthquake and coastal vertical movements, J. Geogr. (Chigaku zasshi), v. 38, pp. 130-135, 188-201, 324-329, 374390, (in Japanese).

Tsumura, N., Komada, N., Sano, J., Kikuchi, S., Yamamoto, S., Ito, T., Sato, T., Miyauchi, T., Kawamura, T., Shishikura, M., Abe, S., Sato, H., Kawanaka, T., Suda, S., Higashinaka, M., and Ikawa, T., 2009, A bump on the upper surface of the Philippine Sea plate beneath the Boso peninsula, Japan inferred from seismic reflection surveys: A possible asperity of the 1703 Genroku earthquake, Tectonophysics, v. 472, pp. 39-50

Uchida, N., Nakajima, J., Hasegawa, A. and Matsuzawa T., 2009, What controls interplatecoupling?: Evidence for abrupt change in coupling across a border between two overlyingplates in the NE Japan subduction zone, Earth Planet. Sci. Lett., v. 283, pp. 111-121.

Uno, T., Miyauchi, T. and Shishikura, M., 2007, Reexamination of earthquakes occurring along the Sagami Trough, analyzed by Holocene marine terraces in the Boso Peninsula, Abstract of Japan Geoscience Union Meeting 2007, S141-007.

Usami, T., M. Uchino and M. Yoshimura, 1977, Historical documents related to the Genroku Earthquake in the southern part of Boso Peninsula, 62p., (in Japanese).

Usami, T., Ishi, H., Imamura, T., Takemura, M. and Matsuura, R., 2013, Materials for comprehensive list of destructive earthquakes in Japan, 599-2012, Univ. Tokyo Press, 694p., (in Japanese).

Wald D. J. and P. G. Somerville, 1995, Variable-slip rupture model of the great 1923 Kanto, Japan, earthquake, Bull. Seism. Soc. Am., v. 85, pp. 159-177.

Watanabe, A., 1929, Marine terraces in the southern part of Boso Peninsula, Geogr. Rev. Japan, v. 5, pp. 119-126, (in Japanese).

Yamasaki, N., 1926, Physiographical studies of the great earthquake of Kwanto district, 1923. Jour. Fac. Sci. Imp. Univ. Tokyo, Sec. v. 2, pp. 77-119, (in Japanese).

Yokota, K., 1978, Holocene coastal terraces on the southern coast of the Boso Peninsula, Geogr. Rev. Japan, Ser. A, v. 51, pp. 349-364, (in Japanese with English abstract and figure captions).

Yonekura, N., 1975, Quaternary tectonic movements in the outer arc of Southwest Japan with special reference to seismic crustal deformation, Bulletin of the Department of Geography, University of Tokyo, v. 7, pp. 19-71. 